\title{
Multi-Walled Carbon Nanotubes Improved Development during In Vitro Multiplication of Sugarcane (Saccharum spp.) in a Semi-Automated Bioreactor
}

\author{
Monserrat Sorcia-Morales ${ }^{1}$, Fernando Carlos Gómez-Merino ${ }^{1}{ }^{\mathbb{D}}$, Lino Sánchez-Segura ${ }^{2}{ }^{\mathbb{D}}$, \\ José Luis Spinoso-Castillo ${ }^{1}$ a and Jericó Jabín Bello-Bello ${ }^{3, *}$ \\ 1 Colegio de Postgraduados Campus Córdoba, Carretera Federal Córdoba-Veracruz km. 348, Veracruz 94946, \\ Mexico; monserrat.sorciam@gmail.com (M.S.-M.); fernandg@colpos.mx (F.C.G.-M.); \\ jlspinoso@gmail.com (J.L.S.-C.) \\ 2 CINVESTAV, Departamento de Ingeniería Genética, Unidad Irapuato, Libramiento Norte Carretera, \\ Irapuato-León km. 9.6, Guanajuato 36824, Mexico; lino.sanchez@cinvestav.mx \\ 3 CONACYT-Colegio de Postgraduados Campus Córdoba, Carretera Federal Córdoba-Veracruz km. 348, \\ Veracruz 94946, Mexico \\ * Correspondence: jericobello@gmail.com; Tel.: +52-271-716-6000
}

Citation: Sorcia-Morales, M.; Gómez-Merino, F.C.; Sánchez-Segura, L.; Spinoso-Castillo, J.L.; Bello-Bello, J.J. Multi-Walled Carbon Nanotubes Improved Development during In Vitro Multiplication of Sugarcane (Saccharum spp.) in a SemiAutomated Bioreactor. Plants 2021, 10, 2015. https://doi.org/10.3390/ plants10102015

Academic Editor: Kamel

A. Abd-Elsalam

Received: 25 August 2021

Accepted: 16 September 2021

Published: 26 September 2021

Publisher's Note: MDPI stays neutral with regard to jurisdictional claims in published maps and institutional affiliations.

Copyright: (c) 2021 by the authors. Licensee MDPI, Basel, Switzerland. This article is an open access article distributed under the terms and conditions of the Creative Commons Attribution (CC BY) license (https:/ / creativecommons.org/licenses/by/ $4.0 /)$.

\begin{abstract}
Carbon nanotubes play an important role in plant biotechnology due to their effects on the growth and differentiation of cells, tissues, organs, and whole plants. This study aimed to evaluate the effect of multi-walled carbon nanotubes (MWCNTs) during in vitro multiplication of sugarcane (Saccharum spp.) using a temporary immersion system. Morphological characterization of MWCNTs was carried out under a transmission electron microscope. Different concentrations $\left(0,50,100,200 \mathrm{mg} \mathrm{L}^{-1}\right)$ of MWCNTs were added to Murashige and Skoog liquid culture medium in the multiplication stage. At $30 \mathrm{~d}$ of culture, number of shoots per explant, shoot length, number of leaves per shoot, total chlorophyll, dry matter percentage, carbon percentage, and macro- and micronutrient content were evaluated. Results showed an increase in the development of sugarcane shoots at concentrations of 100 and $200 \mathrm{mg} \mathrm{L}^{-1}$ MWCNT. Total chlorophyll content increased at concentrations of 50 and $100 \mathrm{mg} \mathrm{L}^{-1}$ MWCNT, whereas macro- and micronutrient content was variable at the different MWCNT concentrations. Results suggest a hormetic effect, characterized by stimulation at low concentrations. In conclusion, the use of low concentrations of MWCNTs had positive effects on development, total chlorophyll, carbon percentage, and macro- and micronutrient $(\mathrm{N}, \mathrm{Ca}, \mathrm{S}, \mathrm{Fe}, \mathrm{Cu}, \mathrm{Zn}$ and $\mathrm{Na}$ ) contents during in vitro multiplication of sugarcane and may have a potential use in other species of agricultural interest.
\end{abstract}

Keywords: in vitro culture; carbon content; chlorophyll; macro- and micronutrients; hormesis

\section{Introduction}

Nanotechnology in agriculture is important for the development of nanopesticides, nanofertilizers, nanogrowth regulators, and nanomaterials to improve agricultural production [1]. Nanomaterials are characterized by an ordered assembly of their atoms to form structures on a manometer scale of between 1 to $100 \mathrm{~nm}[2,3]$. Some examples of carbon nanostructures include fullerene, graphene, nanoparticles, nanofibers, and nanotubes [4,5]. Carbon nanotubes (CNTs) are rolled up sheets of graphene forming a hollow cylindrical structure, and they are classified into single-walled carbon nanotubes (SWCNTs) and multiwalled carbon nanotubes (MWCNTs) [6,7]. Compared to SWCNTs, MWCNTs have higher density, tensile strength, and electrical conductivity [8], as well as lower toxicity in plant cells [9]. Some effects of CNTs on plants have been described, notably their positive effect on development, nutritional status, and photosynthesis. However, the effects of CNTs on plants depend on the species, CNT type, concentration, developmental stage and culture conditions [10]. 
On the other hand, the effects of MWCNTs on plants have only been evaluated in hydroponic cultures of broccoli (Brassica oleracea L.), sunflower (Helianthus annuus L.), and marijuana (Cannabis sativa L.) [11,12]. An alternative to more accurately study the effects of CNTs on plants is by in vitro plant tissue culture. This technique allows the manipulation of cells, tissues, organs, or whole plants under aseptic and controlled conditions. Some recent studies have reported on the administration of MWCNTs in in vitro cultures of sorghum (Sorghum bicolor L. Moench), switchgrass (Panicum virgatum L.), thyme (Thymus daenensis), and African lily (Agapanthus praecox) [13-15]. However, the physiological and biochemical effects and mechanisms of CNTs in plants have not been fully elucidated. This study aimed to evaluate the effect of carbon nanotubes (CNTs) during in vitro multiplication of sugarcane (Saccharum spp.) cv. Mex 69-290 using a temporary immersion system.

\section{Results}

\subsection{Characteristics of Carbon Nanotubes}

The MWCNTs formulation is powder based and with a carbon purity of $98 \%$. Transmission Electron Microscopy (TEM) characterization corroborates the manufacturing dimensions with an outer diameter between 6-13 nm, average length between 2.5-20 $\mu \mathrm{m}$, and preparation by chemical vapor deposition (Figure 1).
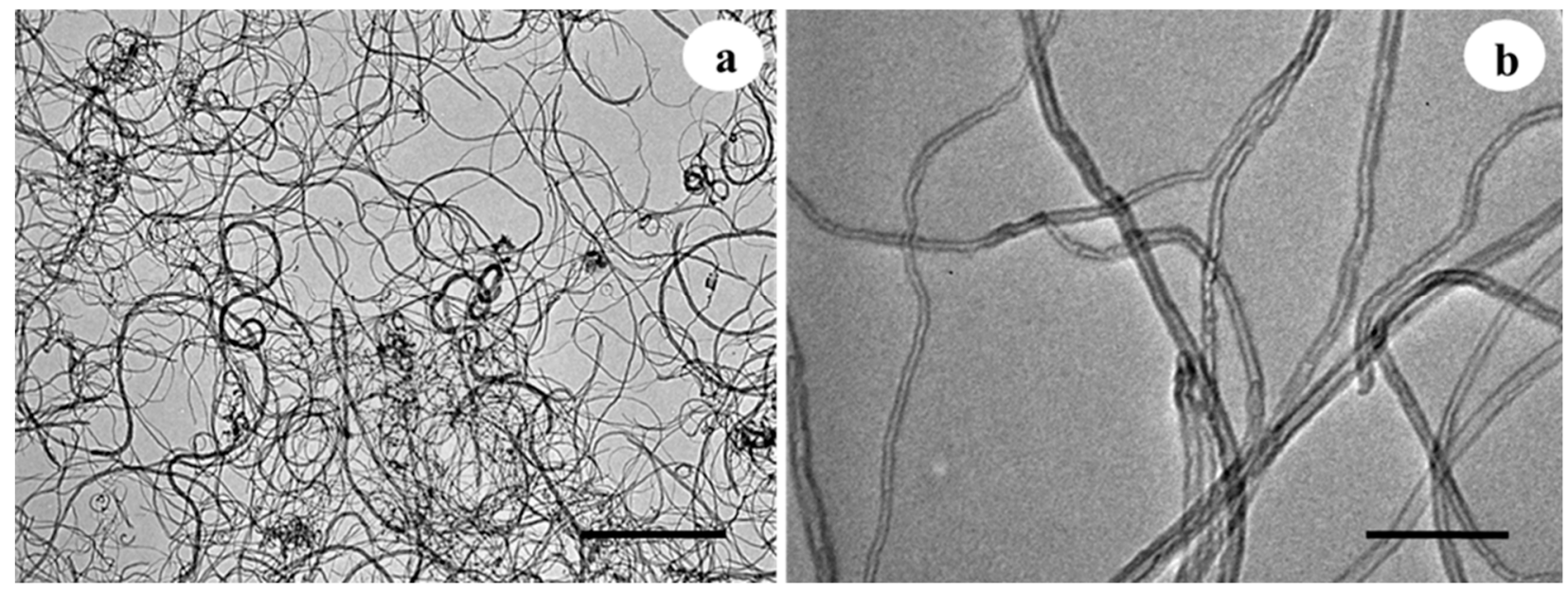

Figure 1. Multi-walled carbon nanotubes (MWCNTs) observed by transmission electron microscopy (TEM) using different magnifications. (a) Black bar $=1000 \mathrm{~nm}$. (b) Black bar $=100 \mathrm{~nm}$.

\subsection{Effect of MWCNTs on Shoot Development, and Chlorophyll and Carbon Content}

The administration of different MWCNT concentrations had a contrasting effect on the number of shoots per explant, shoot length, number of leaves per shoot, total chlorophyll (Chl) content, dry matter (DM) percentage, and carbon (C) percentage in sugarcane shoots cultured in temporary immersion bioreactors (Figure 2). The highest number of shoots per explant was obtained at the concentrations of 100 and $200 \mathrm{mg} \mathrm{L}^{-1}$ MWCNT, with 38.33 and 37.93 shoots per explant, respectively, whereas the lowest number of shoots was observed in the control treatment, with 26.06 shoots per explant (Figure 2a). Regarding shoot length, the highest shoot height was observed at the concentration of $200 \mathrm{mg} \mathrm{L}^{-1} \mathrm{MWCNT}$, with $8.61 \mathrm{~cm}$ in length, whereas the shortest length was observed in the control treatment, with $6.01 \mathrm{~cm}$ in length (Figure 2b). The highest number of leaves per shoot was observed with the concentrations of 100 and $200 \mathrm{mg} \mathrm{L}^{-1}$ MWCNT, with 4.6 and 5.06, respectively, whereas the lowest number of leaves was obtained in the control treatment, with 3.33 leaves per shoot (Figure 2c). For total $\mathrm{Chl}$ content, the highest amount was observed at the concentrations of 50 and $100 \mathrm{mg} \mathrm{L}^{-1}$ MWCNT, with 0.38 and $0.37 \mathrm{mg} \mathrm{g}^{-1} \mathrm{FW}$, respectively, whereas the lowest total $\mathrm{Chl}$ content was observed at the concentrations of 0 and $200 \mathrm{mg} \mathrm{L}^{-1}$ MWCNT, with 0.27 and $0.28 \mathrm{mg} \mathrm{g}^{-1} \mathrm{FW}$, respectively (Figure 2d). For DM percentage, 
the highest content was observed at the concentrations of 100 and $200 \mathrm{mg} \mathrm{L}^{-1} \mathrm{MWCNT}$, with 7.31 and $7.44 \%$ DM, respectively, whereas the lowest content was obtained in the control treatment, with $6.65 \%$ DM (Figure 2e). For $C$ percentage, the highest values were obtained with the concentrations of 100 and $200 \mathrm{mg} \mathrm{L}^{-1}$ MWCNT, with 60.00 and $64.07 \%$, respectively, whereas the lowest $C$ content was obtained with the concentrations of 0 and $50 \mathrm{mg} \mathrm{L}^{-1}$ MWCNT, with 47.39 and 51.25\% carbon, respectively (Figure 2f). In addition, the administration of different MWCNT concentrations had an effect on multiplication rate in sugarcane shoots cultured in temporary immersion bioreactors (TIBs) (Figure 3).
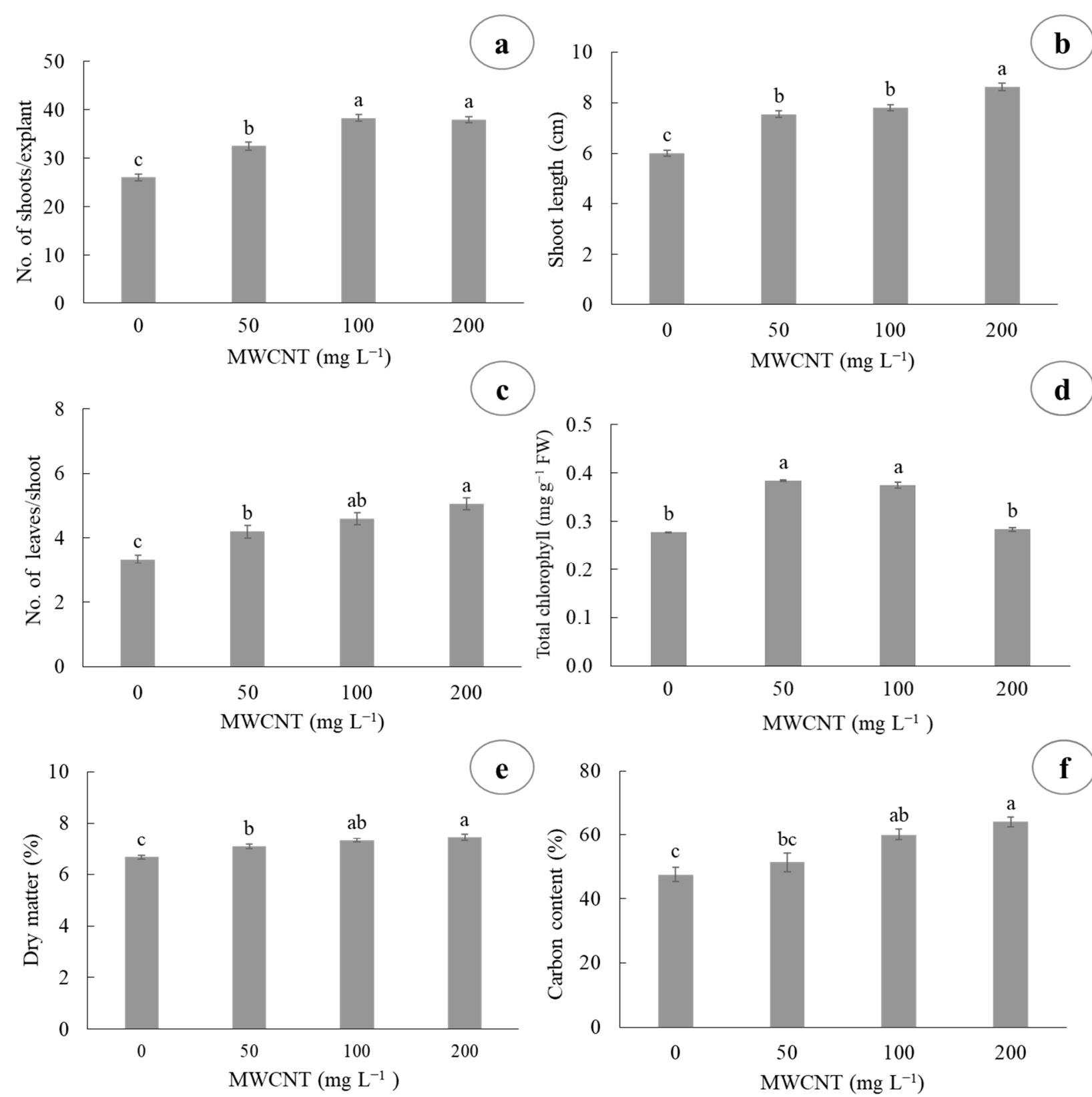

Figure 2. Effect of multi-walled carbon nanotubes (MWCNTs) on shoot development and total chlorophyll and carbon content of sugarcane (Saccharum spp.) cv. Mex 69-290 cultured in vitro in temporary immersion. (a) Shoots per explant, (b) shoot length, (c) leaves per shoot, (d) total chlorophyll, (e) dry matter, and (f) carbon content at 30 days of culture. Results are shown as mean \pm SE (standard error). Means with a different letter are significantly different (Tukey, $p \leq 0.05$ ). 

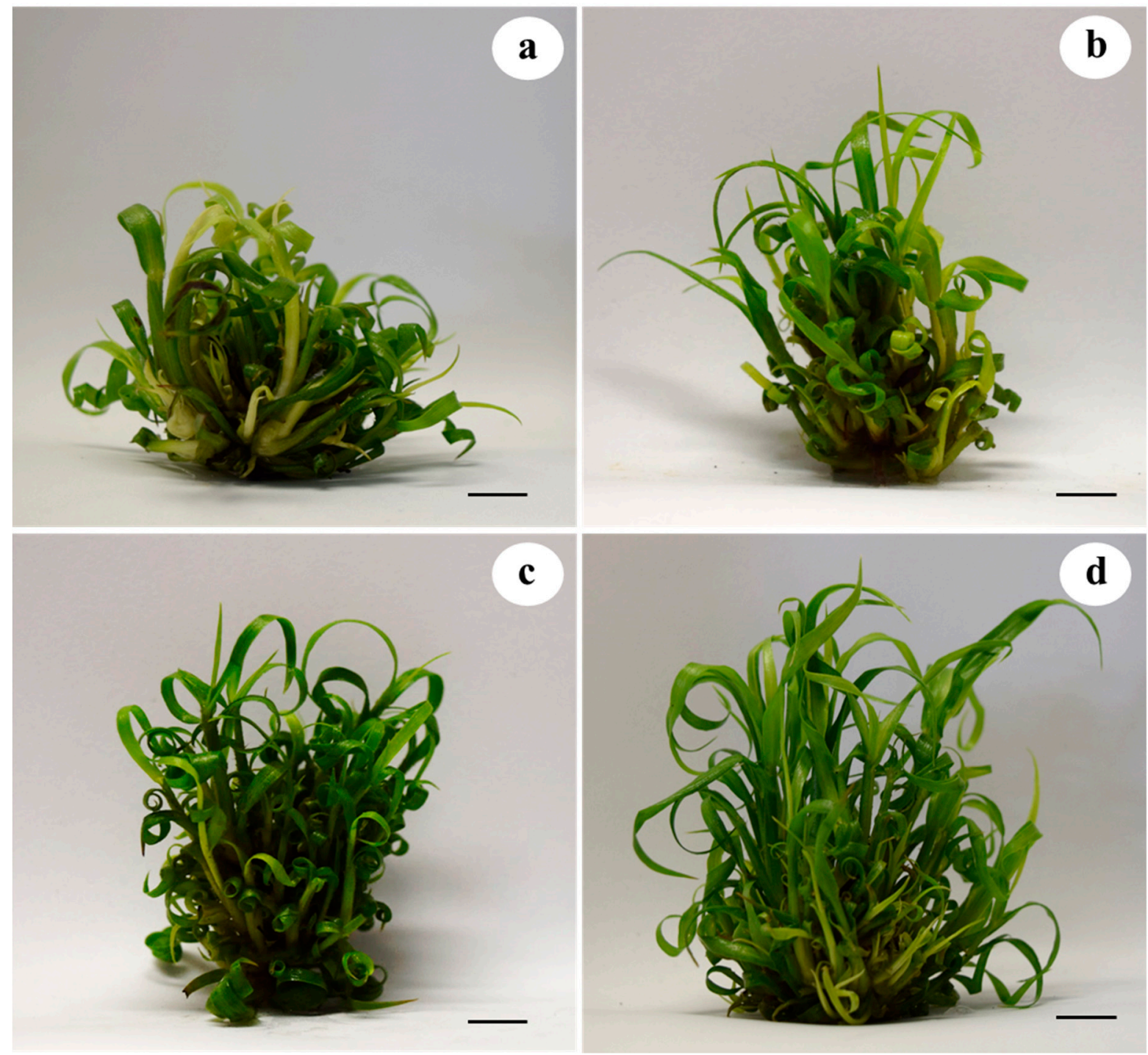

Figure 3. Effect of different MWCNT concentrations on in vitro shoot development of sugarcane (Saccharum spp.) cv. Mex 69-290 at 30 days in temporary immersion; (a-d) 0, 50, 100, and $200 \mathrm{mg} \mathrm{L}^{-1}$ MWCNT, respectively. Black bar $=1 \mathrm{~cm}$.

\subsection{Effect of Carbon Nanotubes on Macro- and Micronutrient Content}

A significant effect of MWCNTs was observed on the content of macronutrients N, Ca, and $\mathrm{S}$, as well as on the content of micronutrients $\mathrm{Fe}, \mathrm{Cu}, \mathrm{Zn}$, and $\mathrm{Na}$ (Table 1). The highest $\mathrm{N}$ contents were observed at concentrations of 0,50 , and $100 \mathrm{mg} \mathrm{L}^{-1}$ MWCNT, with 47,900, 45,800 , and $42,400 \mathrm{mg} \mathrm{kg}^{-1}$, whereas the lowest content was found at concentration of $200 \mathrm{mg} \mathrm{L}^{-1}$, with $39,500 \mathrm{mg} \mathrm{kg}^{-1}$. For the Ca element, the highest content was obtained with the $200 \mathrm{mg} \mathrm{L}^{-1}$ treatment followed by the treatment at $100 \mathrm{mg} \mathrm{L}^{-1}$ MWCNT, with 1848 and $1627 \mathrm{mg} \mathrm{kg}^{-1}$, respectively, whereas the lowest Ca contents were at 0 and $50 \mathrm{mg} \mathrm{L}^{-1}$ MWCNT, with 1425.42 and $1561.81 \mathrm{mg} \mathrm{kg}^{-1}$, respectively. For the macronutrient S, the highest contents were obtained at concentrations of 100 and $200 \mathrm{mg} \mathrm{L}^{-1}$ MWCNT, with values of 3267.52 and $3487.07 \mathrm{mg} \mathrm{kg}^{-1}$, respectively, whereas the lowest $\mathrm{S}$ content was obtained in the treatment without MWCNT, with $3032.37 \mathrm{mg} \mathrm{kg}^{-1}$. The macronutrients $\mathrm{P}$ and $\mathrm{Mg}$ did not show any difference among the treatments. Regarding micronutrients, the highest Fe contents were obtained with the 0,50 , and $100 \mathrm{mg} \mathrm{L}^{-1}$ MWCNT treatments, with $299.49,318.00$, and $322.49 \mathrm{mg} \mathrm{kg}^{-1}$, whereas the lowest Fe content was found in the treatment with $200 \mathrm{mg} \mathrm{L}^{-1} \mathrm{MWCNT}$, with $281.86 \mathrm{mg} \mathrm{kg}^{-1}$. For the micronutrient $\mathrm{Cu}$, the highest content was obtained in the control treatment, with $6.41 \mathrm{mg} \mathrm{kg}^{-1}$, whereas the 
lowest $\mathrm{Cu}$ content was found in the shoots treated with $100 \mathrm{mg} \mathrm{L}^{-1} \mathrm{MWCNT}$, with values between $3.22-3.39 \mathrm{mg} \mathrm{kg}^{-1}$.

Table 1. Effect of multi-walled carbon nanotubes on macro- and micronutrient content of in vitro shoots of sugarcane (Saccharum spp.) cv. Mex 69-290 in temporary immersion.

\begin{tabular}{|c|c|c|c|c|c|c|c|}
\hline \multirow{2}{*}{$\begin{array}{l}\text { MWCNT } \\
\left(\mathrm{mg} \mathrm{L}^{-1}\right)\end{array}$} & \multicolumn{7}{|c|}{ Macronutrients (mg kg ${ }^{-1}$ ) } \\
\hline & $\mathbf{N}$ & $\mathbf{P}$ & $\mathbf{K}$ & $\mathrm{Ca}$ & $\mathrm{Mg}$ & & $S$ \\
\hline 0 & $47,900 \pm 1300^{a}$ & $3288.13 \pm 63.92^{a}$ & $39,156.96 \pm 3609.36^{a}$ & $1425.42 \pm 25.07^{b}$ & $1006.97 \pm 20.32^{\mathrm{a}}$ & 3032. & $\pm 72.02^{b}$ \\
\hline 50 & $45,800 \pm 1400^{a}$ & $3172.63 \pm 84.08^{a}$ & $39,263.50 \pm 4270.20^{a}$ & $1561.81 \pm 14.68^{b}$ & $1008.41 \pm 16.54^{\mathrm{a}}$ & 3267.5 & $\pm 13.44^{\mathrm{ab}}$ \\
\hline 100 & $42,400 \pm 1500^{a b}$ & $3170.66 \pm 126.87^{\mathrm{a}}$ & $36,006.56 \pm 3114.44^{\mathrm{a}}$ & $1627.85 \pm 60.79 \mathrm{ab}$ & $1006.35 \pm 8.31^{\mathrm{a}}$ & 3549. & $\pm 69.46^{\mathrm{a}}$ \\
\hline \multirow[t]{3}{*}{200} & $39,500 \pm 1600^{b}$ & $3304.98 \pm 108.87^{\mathrm{a}}$ & $36,434.70 \pm 4068.33^{\mathrm{a}}$ & $1848.00 \pm 70.56^{\mathrm{a}}$ & $1051.42 \pm 27.62^{\mathrm{a}}$ & 3487.0 & $\pm 122.15^{\mathrm{a}}$ \\
\hline & \multicolumn{7}{|c|}{ Micronutrients ( $\mathrm{mg} \mathrm{kg}^{-1}$ ) } \\
\hline & Fe & $\mathrm{Cu}$ & $\mathrm{Zn}$ & Mn & B & $\mathrm{Ni}$ & $\mathrm{Na}$ \\
\hline 0 & $299.49 \pm 7.04^{\mathrm{ab}}$ & $6.41 \pm 0.38^{a}$ & $69.73 \pm 0.25^{b}$ & $62.04 \pm 0.86^{a}$ & $20.75 \pm 0.43^{a}$ & $1.42 \pm 0.26^{\mathrm{a}}$ & $508.29 \pm 10.86^{a}$ \\
\hline 50 & $318.00 \pm 3.79^{a}$ & $3.32 \pm 0.35^{b}$ & $74.45 \pm 0.93^{\mathrm{ab}}$ & $62.89 \pm 0.64^{\mathrm{a}}$ & $20.17 \pm 0.64^{a}$ & $2.11 \pm 0.50^{\mathrm{a}}$ & $515.24 \pm 9.16^{\mathrm{a}}$ \\
\hline 100 & $322.49 \pm 2.45^{\mathrm{a}}$ & $3.22 \pm 0.17^{b}$ & $76.65 \pm 0.44^{\mathrm{a}}$ & $61.39 \pm 0.42^{\mathrm{a}}$ & $20.20 \pm 0.29^{a}$ & $1.58 \pm 0.90^{\mathrm{a}}$ & $322.45 \pm 1.50^{\mathrm{b}}$ \\
\hline 200 & $281.86 \pm 10.04^{b}$ & $3.39 \pm 0.02^{b}$ & $68.98 \pm 2.61^{b}$ & $64.65 \pm 2.61^{a}$ & $22.45 \pm 0.93^{a}$ & $2.51 \pm 0.79^{\mathrm{a}}$ & $352.95 \pm 16.30^{b}$ \\
\hline
\end{tabular}

Results are shown as mean \pm SE (standard error). Means with a different letter are significantly different (Tukey, $p \leq 0.05)$.

For the element $\mathrm{Zn}$, the highest contents were in the 50 and $100 \mathrm{mg} \mathrm{L}^{-1} \mathrm{MWCNT}$ treatments, with 74.45 and $76.65 \mathrm{mg} \mathrm{kg}^{-1}$, respectively, whereas the lowest contents were at 0 and $200 \mathrm{mg} \mathrm{L}^{-1}$ MWCNT, with 69.73 and $68.98 \mathrm{mg} \mathrm{kg}^{-1}$, respectively. The micronutrients $\mathrm{Mn}, \mathrm{B}$, and $\mathrm{Ni}$ did not show any difference among the treatments. Finally, the highest $\mathrm{Na}$ contents were obtained in shoots treated with 0 and $50 \mathrm{mg} \mathrm{L}^{-1}$ MWCNT, with 508.29 and $515.24 \mathrm{mg} \mathrm{kg}^{-1}$, respectively, whereas the lowest contents were obtained with the concentrations of 100 and $200 \mathrm{mg} \mathrm{L}^{-1} \mathrm{MWCNT}$, with 322.45 and $352.95 \mathrm{mg} \mathrm{kg}^{-1}$, respectively.

\section{Discussion}

\subsection{Plant Development and Carbon Content}

This study shows the effect of MWCNTs during in vitro multiplication of sugarcane. The increase in multiplication rate, shoot length, and number of leaves at concentrations of 100 and $200 \mathrm{mg} \mathrm{L}^{-1}$ MWCNT could be due to increased uptake of nutrients and organic compounds such as sucrose, growth regulators, and vitamins, among others. In this regard, Khodakovskaya et al. [16], working with tobacco (Nicotina tabacum) callus in vitro, observed an increase in biomass of between $55-64 \%$ at a concentration range of 5-500 $\mu \mathrm{g} \mathrm{mL}^{-1}$ MWCNT. Pandey et al. [13], in sorghum (Sorghum bicolor L. Moench) and switchgrass (Panicum virgatum) seeds in vitro, were able to increase the germination rate and root and shoot length at a concentration of $200 \mu \mathrm{g} \mathrm{mL} \mathrm{mWCNT}^{-1}$. Similarly, Seddighinia et al. [17], in bitter melon (Momordica charantia), obtained greater development of shoot and root length, as well as fresh and dry biomass content during germination at $200 \mathrm{mg} \mathrm{L}^{-1} \mathrm{MWCNT}$. This suggests an internalization of the carbon nanotubes in the tissues that also contribute to the increase in \% DW. The authors of [18] reported that, in hopbush (Dodonaea viscosa L.), MWCNTs increased the percentage of seed germination as well as fresh and dry weight of roots and stems at concentrations between 10 and $200 \mathrm{mg} \mathrm{L}^{-1}$ MWCNT. Another study [14] on thyme (Thymus daenensis celak) in vitro, found an increase in the fresh and dry weight of the stems while their height was three times greater than that of the control in seedlings developed with $250 \mu \mathrm{g} \mathrm{mL}^{-1}$ of MWCNT; however, concentrations of 500-2000 $\mathrm{g} \mathrm{mL}^{-1}$ MWCNT had a negative effect on their development.

In this study, the increase in dry weight occurred in response to a higher MWCNT concentration, probably due to a greater accumulation of organic and inorganic compounds that are transported in the tissues by MWCNTs. The major source of carbon was supplied in the form of sucrose and other organic compounds in the MS culture medium (glycine, myo-inositol, nicotinic acid, pyridoxine, and thiamine), the growth regulators Kinetin (KIN), Indoleacetic acid (IAA), and Benzylaminopurine (BAP) and by the C content of the 
MWCNT treatments. The increase in the percentage of total $\mathrm{C}$ is related to the increase in MWCNT concentration.

\subsection{Chlorophyll Content}

The increase in total Chl content at concentrations of 50 and $100 \mathrm{mg} \mathrm{L}^{-1}$ MWCNT could be related to higher photosynthetic activity. In this regard, the authors of [19] and [20], state that CNTs have the ability to move through tissues by forming pores via the apoplastic pathway and via endocytosis until reaching mesophyll cells in leaves, especially within chloroplasts, affecting photosynthetic activity by capturing carbon for energy use and electron transport. Ghasempour et al. [21], working with rose periwinkle (Catharanthus roseu) in vitro, at a concentration of $50 \mathrm{mg} \mathrm{L}^{-1} \mathrm{MWCNT}$, observed the highest amount of biomass, whereas at concentrations of 100 and $150 \mathrm{mg} \mathrm{L}^{-1}$ MWCNT they observed an increase in Chl content. Rahmani et al. [22], working with lilac sage (Salvia verticillata), observed an increase in Chl content at a concentration of $50 \mathrm{mg} \mathrm{L}^{-1}$ MWCNT.

\subsection{Macro- and Micronutrient Content}

The MWCNTs had an effect on the content of some macro- and micronutrients in sugarcane shoots cultured in vitro. As MWCNT concentrations increased, there was a tendency to increase the number of shoots per explant and the length and number of leaves per shoot. This increase in development could be associated with a greater absorption of $\mathrm{N}, \mathrm{Ca}, \mathrm{S}, \mathrm{Fe}$, and $\mathrm{Zn}$; however, the low content of $\mathrm{N}, \mathrm{Fe}$, and $\mathrm{Zn}$ at a concentration of $200 \mathrm{mg} \mathrm{L}^{-1}$ MWCNT could be explained by different hypotheses: (1) a possible depletion of these elements in the culture medium that occurred during the early stages of shoot development, (2) due to greater diffusion caused by a dilution factor of these elements produced by a greater length and number of leaves per shoot and/or (3) due to an exchange of ions through the MWCNTs caused by a concentration gradient inside and outside the cell. This fact could also explain the low chlorophyll content obtained with the $200 \mathrm{mg} \mathrm{L}^{-1}$ MWCNT concentration, probably associated with a low amount of $\mathrm{N}$ and Fe, essential elements in chlorophyll synthesis. Similar results were reported by the authors of [23] in rice (Oryza sativa L.), where rapid root growth caused a significant decrease in $\mathrm{N}$ content, indicating that MWCNTs significantly decreased N assimilation. Another study [24] reported that $\mathrm{K}$ content decreased and Ca content increased during in vitro germination of maize (Zea mays) from $5 \mathrm{mg} \mathrm{L}^{-1}$ MWCNT. The Ca decreased from $20 \mathrm{mg} \mathrm{L}^{-1}$ MWCNT, whereas the content of $\mathrm{P}, \mathrm{Mg}$, and $\mathrm{Na}$ increased from $20 \mathrm{mg} \mathrm{L}^{-1}$ MWCNT and decreased from $50 \mathrm{mg} \mathrm{L}^{-1}$ MWCNT. The Fe content increased from $50 \mathrm{mg} \mathrm{L}^{-1} \mathrm{MWCNT}$ and decreased from $200 \mathrm{mg} \mathrm{L}^{-1}$ MWCNT; $\mathrm{S}$ was not affected. These authors suggest that the increase and decrease of elements may be due to an ion exchange mechanism in the cell wall caused by MWCNTs. Taha et al. [25], found that on in vitro-grown date palm (Phoenix dactylifera) shoots, the content of $\mathrm{N}$ and $\mathrm{P}$ increased at the concentration of $0.1 \mathrm{mg} \mathrm{L}^{-1}$ MWCNT, whereas $\mathrm{K}$ and $\mathrm{Ca}$ had an increase at the concentration of $0.05 \mathrm{mg} \mathrm{L}^{-1}$ MWCNT; on the other hand, Na content decreased as the concentration of carbon nanotubes increased; this could demonstrate the ability of nanotubes to transport $\mathrm{Na}$ ions from the inside to the outside of cells.

The CNTs have the ability to transport heavy metals $(\mathrm{Cu}, \mathrm{Cd}, \mathrm{Zn}, \mathrm{Pb})$ without energy expenditure; however, the uptake of these metals depends on the CNT concentration, heavy metal, and plant genotype [12,19], simulating a chelating effect. Martinez-Ballesta et al. [10], working with broccoli (Brassica oleracea L.) protoplasts, observed that $\mathrm{P}$ and $\mathrm{Fe}$ content increased at $10 \mathrm{mg} \mathrm{L}^{-1}$ MWCNT.

This study demonstrated the potential use of carbon nanotubes during in vitro propagation of sugarcane, as they play an important role in plant development. Lahiani et al. [26] state that carbon nanotubes have the ability to penetrate plant cells and at high concentrations can act as a stress factor, affecting the overexpression of aquaporins, which are important transmembrane channels for transporting water and small solutes such as urea, 
ammonia, metalloids, gases, and even ions. Aquaporins are regulated in response to multiple hormonal and environmental stimuli, which contribute to various plant growth and development processes [27,28]. On the other hand, according to the authors of [29], the internalization of MWCNTs in cells could be through the pores of the cell wall, causing their expansion with different effects on plant development according to their concentration. Zhai et al. [30], working with soybean (Glycine max), demonstrated the presence of MWCNTs in the cytoplasm, cell wall, cell membrane, chloroplast, and mitochondria. According to the authors of [31], in wild sugarcane (Saccharum spontaneum) genotypes the pore diameter in cells ranges from 3.65 to $9.71 \mathrm{~nm}$. The MWCNTs used in this study ranged in diameter from 6 to $13 \mathrm{~nm}$. This indicates that a percentage of MWCNTs could probably penetrate and expand inside Saccharum spp. cells through the pores causing the effects described in this study. Furthermore, the results obtained suggest a hormetic effect, characterized by stimulation at low doses and inhibition at high doses; however, it is necessary to evaluate concentrations higher than $200 \mathrm{mg} \mathrm{L}^{-1}$ MWCNT. The hormetic effect in plants is related to the activation of antioxidant enzymes in response to a low production of reactive oxygen species (ROS) caused by a stressful stimulus. Another study [32], in tomato (Solanum lycopersicum), demonstrated an increase in antioxidant capacity at concentrations of 10-100 $\mathrm{mg} \mathrm{L}^{-1}$ MWCNT and toxicity at 250-1000 $\mathrm{mg} \mathrm{L}^{-1} \mathrm{MWCNT}$.

On the other hand, other authors state that MWCNTs could act as growth regulators, since at low concentrations they impact plant development [24,33]. In addition, the authors of [34] state that the effect of CNTs could be related to plant species, developmental stage, and growth conditions, as well as the type of nanotubes, their size and concentration.

This study showed that MWCNTs have an effect on shoot growth and differentiation, photosynthetic pigment content, and macro- and micronutrient content. In addition, MWCNTs have an effect on nutrient uptake, resulting in an increase in the multiplication rate of sugarcane shoots. These results open up the possibility of applying MWCNTs for in vitro multiplication in other crops of agricultural interest.

\section{Materials and Methods}

\subsection{Characterization of Multi-Walled Carbon Nanotubes}

Multi-walled carbon nanotubes (MWCNTs) (CAS: 308068-56-6) (Sigma-Aldrich ${ }^{\circledR}$ Chemical Company, St. Louis, MO, USA) were used. The nanotubes (1 mg MWCNT) were dissolved in $1 \mathrm{~mL}$ isopropanol (Sigma-Aldrich ${ }^{\circledR}$ ) and dispersed in two 10-min agitation cycles (Super Mixer, LAB LINE; Melrose Park, IL, USA) and 2 sonication cycles (Ultrasonic equipment, PS-20A, Shenzhen Jie Tai Co., LTD, Shenzhen, China) at $40 \mathrm{KHz}$, for $10 \mathrm{~min}$ at $25{ }^{\circ} \mathrm{C}$. Morphological characterization of the nanotubes was performed under a transmission electron microscope (TEM) (Morgagni M-268, Philips/FEI, EI, NL). The MWCNT sample was taken in a $5 \mu \mathrm{L}$ aliquot (1 mg MWCNT/10 mL sterile destined water) and deposited on a 200 mesh Formvar-carbon coated copper grid. Sample drying was performed at room temperature for $5 \mathrm{~min}$. Microscope operating conditions were $80 \mathrm{Kv}$ high voltage (HV), low magnification at 14,000X and high magnification at 200,000X, and column working pressure of $5 \times 10^{-3} \mathrm{~Pa}\left(5 \times 10^{-5}\right.$ Torr $)$. All micrographs were captured in .tiff format with a size of $1376 \times 1032$ pixels in grayscale format.

\subsection{Establishment of In Vitro Sugarcane Explants}

For the establishment of in vitro cultures, apices of approximately $30 \mathrm{~cm}$ in size were collected from four-month-old plants. The apices were reduced to a length of $15 \mathrm{~cm}$ and placed in thermo-hydrotherapy in a circulating thermostatic bath (Ecoshel, SC-15, McAllen, TX, USA) at $50{ }^{\circ} \mathrm{C}$ for $20 \mathrm{~min}$. Subsequently, the apices were reduced to $1.5 \mathrm{~cm}$, rinsed for five $\min$ in a $10 \%(v / v)$ solution of a commercial chlorine bleach, Cloralex ${ }^{\mathrm{TM}}$ (Industrias Alen, S.A. de C.V., Santa Catarina, NL, Mexico) (5\% a.i.), with three drops of Tween $20^{\circledR}$ $\left(\right.$ Sigma-Aldrich ${ }^{\circledR}$ ) per $100 \mathrm{~mL}$ of water. The apices were rinsed three times with sterile distilled water. Finally, the explants were individually placed in test tubes containing $10 \mathrm{~mL}$ MS [35] culture medium supplemented with $30 \mathrm{~g} \mathrm{~L}^{-1}$ sucrose and without growth 
regulators. The $\mathrm{pH}$ of the culture medium was adjusted to $5.8 ; 0.25 \%(w / v)$ Phytagel $^{\mathrm{TM}}$ (Sigma-Aldrich ${ }^{\circledR}$ ) was added as a gelling agent and sterilized in the autoclave for $15 \mathrm{~min}$ at $120^{\circ} \mathrm{C}$ and $115 \mathrm{kPa}$. The explants were incubated at $24 \pm 2{ }^{\circ} \mathrm{C}$, under irradiance of $40 \pm 5 \mu \mathrm{mol} \mathrm{m}^{-2} \mathrm{~s}^{-1}$ and a photoperiod of $16 \mathrm{~h}$ of light. After one week of culture, the apices were transferred for the multiplication phase to MS culture medium supplemented with $30 \mathrm{~g} \mathrm{~L}^{-1}$ sucrose, $1 \mathrm{mg} \mathrm{L}^{-1}$ Kinetin (KIN), $0.6 \mathrm{mg} \mathrm{L}^{-1}$ Indoleacetic acid (IAA) and $0.6 \mathrm{mg} \mathrm{L}^{-1}$ Benzylaminopurine (BAP). All reagents were Sigma-Aldrich ${ }^{\circledR}$ products. After three subcultures $(30 \mathrm{~d}$ each) in the multiplication phase in semisolid medium, shoots were taken as an explant source for the experiments with MWCNTs.

\subsection{Application of Carbon Nanotubes in In Vitro Cultures}

The semi-automated bioreactor used was a temporary immersion bioreactor (TIB) described by Escalona et al. [36]. The bioreactor consists of two jars; a jar for growing explants and the other jar containing the culture medium, the jars are connected with a platinum-cured silicone tubing. Air pressure is applied to the medium container to immerse the explants. After immersion time, a solenoid valve prevents the passage of air and the medium returns to the original jar. The TIBs with $1000 \mathrm{~mL}$ capacity were used. The jar of culture medium was filled with $500 \mathrm{~mL}$ of culture medium and sterilized at $120^{\circ} \mathrm{C}$ for $20 \mathrm{~min}$. In the jar of explants were placed ten explants ( 2 shoots each) with a length of $2 \mathrm{~cm}$. The immersion time was 2 min every $8 \mathrm{~h}$ for 30 days. Incubation conditions were the same as described above.

\subsection{Evaluation of Macro- and Micronutrient Content}

To determine macro- and micronutrient content, samples were dried at $70{ }^{\circ} \mathrm{C}$ in a drying oven for $72 \mathrm{~h}$ and pulverized in a blender (Oster 6832, Milwaukee, WI, USA). Samples were subjected to wet digestion in a mixture of perchloric and nitric acids at a 2:1 $(v / v)$ ratio, according to the protocol described by Alcántar and Sandoval [37]. To determine the concentrations of macronutrients $(\mathrm{P}, \mathrm{K}, \mathrm{Ca}, \mathrm{Mg}$, and $\mathrm{S})$ and micronutrients $(\mathrm{B}, \mathrm{Cu}, \mathrm{Fe}, \mathrm{Mn}, \mathrm{Ni}$, and $\mathrm{Zn}$ ), the extracts were analyzed using a coupled plasma induction optical emission spectrometer (ICP-OES, Varian 725-ES, Agilent; Mulgrave, VIC, Australia). The $\mathrm{N}$ concentration was determined by the semi-microkjeldahl method according to the protocol described by Bremner [38].

\subsection{Quantification of Carbon Content}

The $C$ content was determined according to the authors of [39] method. Samples of $100 \mathrm{mg}$ from each treatment were subjected to digestion in a mixture of $10 \mathrm{~mL}$ of $1 \mathrm{~N}$ potassium dichromate and $20 \mathrm{~mL}$ of $0.1 \mathrm{~N}$ concentrated sulfuric acid. Subsequently, the mixture was carried out in $500 \mathrm{~mL}$ Erlenmeyer flasks and shaken manually for $1 \mathrm{~min}$. The $\mathrm{C}$ quantification was performed by titration with $0.05 \mathrm{~N}$ ferrous sulfate heptahydrate.

\subsection{Chlorophyll Content}

Total chlorophyll content was determined according to the methodology proposed by Harborne [40]. For each sample, $1 \mathrm{~g}$ of fresh matter was macerated with $80 \%$ acetone and left to stand at $-4{ }^{\circ} \mathrm{C}$ for $24 \mathrm{~h}$ in $80 \%$ acetone at final volume of $10 \mathrm{~mL}$. Subsequently, the mixture was filtered with No. 41 filter paper and adjusted to a volume of $25 \mathrm{~mL}$ with $80 \%$ acetone. Two $\mathrm{mL}$ per sample were used at an absorbance of 663 and $645 \mathrm{~nm}$ for chlorophyll $a$ and $b$, respectively. Readings were performed using a spectrophotometer (Genesys 10S, Thermo Scientific, Waltham, MA, USA). Finally, quantification was performed using the following Equation (1):

$$
\text { Total chlorophyll }=[[(8.20 \times \mathrm{A} 663)-(20.20 \times \mathrm{A} 645)](\mathrm{V})] /(1000 \times \mathrm{W})
$$

where A645 and A645: absorbance, V: graduation volume in $\mathrm{mL}^{-1}, \mathrm{~W}$ : sample weight in $\mathrm{g}$, and 1000 is the conversion factor. 


\subsection{Experimental Design and Statistical Analysis}

A completely randomized experimental design was used. All experiments were performed in triplicate. Data were subjected to one-way analysis of variance (ANOVA) and Tukey's mean comparison $(p \leq 0.05)$ using IBM SPSS ${ }^{\circledR}$ statistical software (version 22 for Windows).

\section{Conclusions}

In conclusion, it was demonstrated that the administration of MWCNTs at low concentrations produce favorable physiological effects on development in the in vitro multiplication stage of sugarcane using temporary immersion bioreactors. These results demonstrated that MWCNTs can induce a hormetic effect during in vitro shoot multiplication of sugarcane and may have a potential use in other species. In addition, MWCNTs provide applications to improve crop production by increasing the efficiency during micropropagation.

Author Contributions: Conceptualization, F.C.G.-M., L.S.-S. and J.L.S.-C.; data curation, M.S.-M.; formal analysis, M.S.-M.; methodology, J.J.B.-B.; project administration, J.J.B.-B.; writing—original draft, M.S.-M.; writing—review and editing, F.C.G.-M., L.S.-S. and J.L.S.-C. All authors have read and agreed to the published version of the manuscript.

Funding: The CONACYT-Colegio de Postgraduados Campus Córdoba financially supported the study.

Institutional Review Board Statement: Not applicable.

Informed Consent Statement: Not applicable.

Data Availability Statement: Not applicable.

Conflicts of Interest: The authors declare no conflict of interest.

\section{References}

1. Usman, M.; Farooq, M.; Wakeel, A.; Nawaz, A.; Cheema, S.A.; Rehman, A.H.; Sanaullah, M. Nanotechnology in agriculture: Current status, challenges and future opportunities. Sci. Total Environ. 2020, 721, 137778. [CrossRef] [PubMed]

2. Shang, Y.; Hasan, M.K.; Ahammed, G.J.; Li, M.; Yin, H.; Zhou, J. Applications of Nanotechnology in Plant Growth and Crop Protection: A Review. Molecules 2019, 24, 2558. [CrossRef] [PubMed]

3. Mali, S.C.; Raj, S.; Trivedi, R. Nanotechnology a novel approach to enhance crop productivity. Biochem. Biophys. Rep. 2020, $24,100821$.

4. Verma, S.K.; Das, A.K.; Gantait, S.; Kumar, V.; Gurel, E. Applications of carbon nanomaterials in the plant system: A perspective view on the pros and cons. Sci. Total Environ. 2019, 667, 485-499. [CrossRef] [PubMed]

5. Saleem, H.; Zaidi, S.J. Recent developments in the application of nanomaterials in agroecoystems. Nanomaterials 2020, $10,2411$. [CrossRef] [PubMed]

6. Ahmad, M.; Silva, S.R.P. Low temperature growth of carbon nanotubes-A review. Carbon 2020, 158, 24-44. [CrossRef]

7. Paramo, L.A.; Feregrino-Pérez, A.A.; Guevara, R.; Mendoza, S.; Esquivel, K. Nanoparticles in agroindustry: Applications, toxicity, challenges, and trends. Nanomaterials 2020, 10, 1654. [CrossRef] [PubMed]

8. Shoukat, R.; Khan, M.I. Carbon nanotubes: A review on properties, synthesis methods and applications in micro and nanotechnology. Microsyst. Technol. 2021, 1-10. [CrossRef]

9. Samadi, S.; Lajayer, B.A.; Moghiseh, E.; Rodríguez-Couto, S. Effect of carbon nanomaterials on cell toxicity, biomass production, nutritional and active compound accumulation in plants. Environ. Technol. Innov. 2021, 21, 1-24. [CrossRef]

10. Martinez-Ballesta, M.C.; Chelbi, N.; Lopez-Zaplana, A.; Carvajal, M. Discerning the mechanism of the multiwalled carbon nanotubes effect on root cell water and nutrient transport. Plant Physiol. Biochem. 2020, 146, 23-30. [CrossRef]

11. Martínez-Ballesta, M.C.; Zapata, L.; Chalbi, N.; Carvajal, M. Multiwalled carbon nanotubes enter broccoli cells enhancing growth and water uptake of plants exposed to salinity. J. Nanobiotechnol. 2016, 14, 42. [CrossRef]

12. Oloumi, H.; Mousavi, E.A.; Nejad, R.M. Multi-wall carbon nanotubes effects on plant seedlings growth and cadmium/lead uptake in vitro. Russ. J. Plant Physiol. 2018, 65, 260-268. [CrossRef]

13. Pandey, K.; Lahiani, M.H.; Hicks, V.K.; Keith Hudson, M.; Green, M.J.; Khodakovskaya, M. Effects of carbon-based nanomaterials on seed germination, biomass accumulation and salt stress response of bioenergy crops. PLoS ONE 2018, 13, e0202274. [CrossRef]

14. Samadi, S.; Saharkhiz, M.J.; Azizi, M.; Samiei, L.; Ghorbanpour, M. Multi-walled carbon nanotubes stimulate growth, redox reactions and biosynthesis of antioxidant metabolites in Thymus daenensis celak. in vitro. Chemosphere 2020, 249, 126069. [CrossRef] [PubMed] 
15. Ren, L.; Deng, S.; Chu, Y.; Zhang, Y.; Zhao, H.; Chen, H.; Zhang, D. Single-wall carbon nanotubes improve cell survival rate and reduce oxidative injury in cryopreservation of Agapanthus praecox embryogenic callus. Plant Methods 2020, 16, 1-12. [CrossRef] [PubMed]

16. Khodakovskaya, M.V.; De Silva, K.; Biris, A.S.; Dervishi, E.; Villagarcia, H. Carbon nanotubes induce growth enhancement of tobacco cells. ACS Nano 2012, 6, 2128-2135. [CrossRef] [PubMed]

17. Seddighinia, F.S.; Iranbakhsh, A.; Ardebili, Z.O.; Satari, T.N.; Soleimanpour, S. Seed priming with cold plasma and multi-walled carbon nanotubes modified growth, tissue differentiation, anatomy, and yield in bitter melon (Momordica charantia). J. Plant Growth Regul. 2020, 39, 87-98. [CrossRef]

18. Yousefi, S.; Kartoolinejad, D.; Naghdi, R. Effects of priming with multi-walled carbon nanotubes on seed physiological characteristics of Hopbush (Dodonaea viscosa L.) under drought stress. Int. J. Environ. Sci. 2017, 74, 528-539.

19. Sun, C.; Li, W.; Xu, Y.; Hu, N.; Ma, J.; Cao, W.; Huang, Q. Effects of carbon nanotubes on the toxicities of copper, cadmium and zinc toward the freshwater microalgae Scenedesmus obliquus. Aquat. Toxicol. 2020, 224, 105504. [CrossRef]

20. López-Vargas, E.R.; González-García, Y.; Pérez-Álvarez, M.; Cadenas-Pliego, G.; González-Morales, S.; Benavides-Mendoza, A.; Juárez-Maldonado, A. Seed Priming with Carbon Nanomaterials to Modify the Germination, Growth, and Antioxidant Status of Tomato Seedlings. Agronomy 2020, 10, 639. [CrossRef]

21. Ghasempour, M.; Iranbakhsh, A.; Ebadi, M.; Ardebili, Z.O. Multi-walled carbon nanotubes improved growth, anatomy, physiology, secondary metabolism, and callus performance in Catharanthus roseus: An in vitro study. 3 Biotech 2019, 9, 404. [CrossRef]

22. Rahmani, N.; Radjabian, T.; Soltani, B.M. Impacts of foliar exposure to multi-walled carbon nanotubes on physiological and molecular traits of Salvia verticillata L., as a medicinal plant. Plant Physiol. Biochem. 2020, 150, 27-38. [CrossRef]

23. Hao, Y.; Yu, F.; Lv, R.; Ma, C.; Zhang, Z.; Rui, Y.; Xing, B. Carbon nanotubes filled with different ferromagnetic alloys affect the growth and development of rice seedlings by changing the $\mathrm{C}$ : $\mathrm{N}$ ratio and plant hormones concentrations. PLoS ONE 2016, 11, e0157264.

24. Tiwari, D.K.; Dasgupta-Schubert, N.; Cendejas, L.V.; Villegas, J.; Montoya, L.C.; García, S.B. Interfacing carbon nanotubes (CNT) with plants: Enhancement of growth, water and ionic nutrient uptake in maize (Zea mays) and implications for nanoagriculture. Appl. Nanosci. 2014, 4, 577-591. [CrossRef]

25. Taha, R.A.; Hassan, M.M.; Ibrahim, E.A.; Abou Baker, N.H.; Shaaban, E.A. Carbon nanotubes impact on date palm in vitro cultures. PCTOC 2016, 127, 525-534. [CrossRef]

26. Lahiani, M.H.; Dervishi, E.; Chen, J.; Nima, Z.; Gaume, A.; Biris, A.S.; Khodakovskaya, M.V. Impact of carbon nanotube exposure to seeds of valuable crops. ACS Appl. Mater. Interfaces 2013, 5, 7965-7973. [CrossRef]

27. Li, G.; Santoni, V.; Maurel, C. Plant aquaporins: Roles in plant physiology. Biochim. Biophys. Acta 2014, 1840, 1574-1582. [CrossRef] [PubMed]

28. Verdoucq, L.; Maurel, C. Plant aquaporins. Adv. Bot. Res. 2018, 87, 25-56.

29. Zhao, Q.; Ma, C.; White, J.C.; Dhankher, O.P.; Zhang, X.; Zhang, S.; Xing, B. Quantitative evaluation of multi-wall carbon nanotube uptake by terrestrial plants. Carbon 2017, 114, 661-670. [CrossRef]

30. Zhai, G.; Gutowski, S.M.; Walters, K.S.; Yan, B.; Schnoor, J.L. 2Charge, size, and cellular selectivity for multiwall carbon nanotubes by maize and soybean. Environ. Sci. Technol. 2015, 49, 7380-7390. [CrossRef] [PubMed]

31. Selvaraj, A.; Gobikrishnan, S. Physicochemical Characterization of Native and Steam Explosion Pretreated Wild Sugarcane (Saccharum spontaneum). Int. J. Renew. Energy Dev. 2020, 9, 3. [CrossRef]

32. González-García, Y.; López-Vargas, E.R.; Cadenas-Pliego, G.; Benavides-Mendoza, A.; González-Morales, S.; Robledo-Olivo, A.; Juárez-Maldonado, A. Impact of carbon nanomaterials on the antioxidant system of tomato seedlings. Int. J. Mol. Sci. 2019, 20, 5858. [CrossRef] [PubMed]

33. Khodakovskaya, M.; Dervishi, E.; Mahmood, M.; Xu, Y.; Li, Z.; Watanabe, F.; Biris, A.S. Carbon nanotubes are able to penetrate plant seed coat and dramatically affect seed germination and plant growth. ACS Nano 2009, 3, 3221-3227. [CrossRef] [PubMed]

34. Mathew, S.; Tiwari, D.K.; Tripathi, D. Interaction of carbon nanotubes with plant system: A review. Carbon Lett. 2020, 31, 1-10. [CrossRef]

35. Murashige, T.; Skoog, F. A revised medium for rapid growth and bio assays with tobacco tissue cultures. Physiol. Plant. 1962, 15, 473-497. [CrossRef]

36. Escalona, M.; Lorenzo, J.C.; González, B.; Daquinta, M.; González, J.L.; Desjardins, Y.; Borroto, C.G. Pineapple (Ananas comosus L. Merr) micropropagation in temporary immersion systems. Plant Cell Rep. 1999, 18, 743-748. [CrossRef]

37. Alcántar, G.G.M.; Sandoval, V. Manual de Análisis Químico de Tejido Vegetal; Publicación Especial 10; Sociedad Mexicana de la Ciencia del Suelo: Chapingo, Mexico, 1999.

38. Bremner, J.T. Inorganic forms of nitrogen. In Methods of Soil Analysis: Part 2 Chemical and Microbiological Properties; John Wiley\&Sons, Inc.: Hoboken, NJ, USA, 1965; Volume 9, pp. 1179-1237.

39. Walkley, A.; Black, I.A. An examination of the Degtjareff method for determining soil organic matter, and a proposed modification of the chromic acid titration method. Soil Sci. 1934, 37, 29-38. [CrossRef]

40. Harborne, J.B. Phenolic compounds. In Phytochemical Methods; Springer: Dordrecht, The Netherlands, 1973 ; pp. 33-88. 